\title{
Munich, Bayerische Staatsbibliothek, Clm 6298: a new witness of the biblical commentaries from the Canterbury School
}

\author{
EVINA STEINOVA
}

\begin{abstract}
A B S TR ACT
Manuscript Munich, Bayerische Staatsbibliothek, Clm 6298 contains an as yet unexamined fragment of the second batch of the gospel glosses (EvII) from the biblical commentaries of the Canterbury School inserted as an addition in 3r of the manuscript. In this article, I describe this fragment, and I attempt to contextualize its insertion into the manuscript. It seems likely that the glosses were entered into the manuscript, together with some additional excerpts in the same folio, either in one of the centres in the Anglo-Saxon missionary area in Germany, where the manuscript originated, or at Freising, where the manuscript was kept at a later date.
\end{abstract}

The re-discovery of the textual heritage of the seventh-century Canterbury school may be considered one of the landmarks of the recent manuscript scholarship. Bernhard Bischoff was the first to draw attention to Milan, Biblioteca Ambrosiana, M 79 sup., an eleventh-century manuscript from Northern Italy which contains large portions of the corpus of the biblical glosses that may be associated with Theodore and Hadrian, the great scholars of the Canterbury school. ${ }^{1}$ In their impressive edition cum commentary ${ }^{2}$ Bischoff and Lapidge identified some twenty-five manuscripts that preserve portions of the same commentary corpus. ${ }^{3}$ Of these, only the rather late Milanese manuscript contains larger portions of the corpus and as such provided the basis of Bischoff's

1 B. Bischoff, 'Wendepunkte in der Geschichte der lateinischen Exegese im Frühmittelalter', Sacris erudiri 6:2 (1954), 189-281, at 191-5. In this article, I will refer to the English translation; B. Bischoff, 'Turning-points in the History of Latin Exegesis in the Early Middle Ages', Biblical Studies: the Medieval Irish Contribution, ed. M. McNamara, Proc. of the Irish Biblical Assoc. 1 (Dublin, 1976), 74-160, at 75-7.

2 B. Bischoff and M. Lapidge, Biblical Commentaries from the Canterbury School of Theodore and Hadrian, CSASE 10 (Cambridge, 1994).

3 Bischoff and Lapidge, Biblical Commentaries, pp. 275-95. See also M. Lapidge, 'The School of Theodore and Hadrian', ASE 15 (1986), 45-72, at 67-72. 


\section{Evina Steinova}

and Lapidge's edition. ${ }^{4}$ The other, older manuscript witnesses preserve only fragments of the commentaries, including some that are not present in the Milanese manuscript, and disclose that the corpus was once probably more substantial, and seems to be abridged in all known witnesses. ${ }^{5}$ The history of the text, sadly, remains at places fragmentary, just as do the commentaries themselves. We do not know when and how the corpus reached the Continent and what the dynamics of its early dissemination were. Nor is it possible to say where exactly many of the oldest manuscripts that contain the commentaries were copied and used, and how they thus might be related to each other.

In this article, I would like to throw light on another witness of the biblical commentaries of Theodore and Hadrian and hopefully add one more piece into the puzzle of the history of the text. During my examination of the digital facsimiles of the manuscript Munich, Bayerische Staatsbibliothek, Clm 6298, I noticed that among the additions made by several hands on $3 \mathrm{r}$ of this manuscript there are two biblical glosses: ${ }^{6}$

Corban. communis locus ubi aelimosinae populi congregantur inde aluntur sacerdotes. Magdalena. nomen loci

These two glosses are identical with items 58 and 59 in the so-called second batch of the gospel glosses (EvII) from the biblical commentaries of Theodore and Hadrian:

Corbanan [Matthew XXVII.6]: communis locus ubi elemosinae populi congregantur; inde aluntur sacerdotes.

Magdalena [Matthew XXVII.56]: nomen de loco. ${ }^{7}$

It may be noted that not only the wording but also the sequence of the two glosses correspond to the most substantial witness of EvII, the Milanese manuscript. The impression is thus that they were taken from a source, whether we should think of the complete EvII or a selection from the commentary, which resembled the material as now preserved in Milan M 79 sup., including the possible omissions and re-shuffling the latter manuscript might contain. $^{8}$

${ }^{4}$ The manuscript is described in Bischoff and Lapidge, Biblical Commentaries, pp. 275-87. See also Bischoff, 'Turning-points', p. 75.

5 Bischoff and Lapidge, Biblical Commentaries, p. 291.

${ }^{6}$ The notices in 3r are transcribed and partially identified in G. Glauche, Katalog der lateinischen Handschriften der Bayerischen Staatsbibliothek. München: Die Pergamenthandschriften aus dem Domkapitel Freising: Bd. 1. Clm 6201 - 6316 (Wiesbaden, 2000), p. 173.

7 Bischoff and Lapidge, Biblical Commentaries, p. 406.

${ }^{8}$ Note the gap between Matthew XXVII.6 and Matthew XXVII.56 in both witnesses. EvII also contains a gloss on Matthew XXVII.32 in the Milanese manuscript, which, however, appears as EvII 61, thus after EvII 59 on Matthew XXVII.56. 
THE OLDEST WITNESSES OF EVII

The EvII glosses are one of the clusters of the biblical commentary of the Canterbury school for which few witnesses are known. Unlike the set of glosses designated by Bischoff and Lapidge as PentII, the Old Testament glosses, and EvI, which became incorporated into the so-called Rz glosses and the Leiden Glossary, ${ }^{9}$ we lack evidence that the EvII glosses and the PentI glosses closely tied with them were widely known. ${ }^{10}$

Beside Clm 6298, there are only three known witnesses of EvII older than Milan M 79 sup: Würzburg, Universitätsbibliothek, M.p.th.f. 47; Würzburg, Universitätsbibliothek, M.p.th.f. 38; and Munich, Bayerische Staatsbibliothek, Clm 14470. ${ }^{11}$ All can be dated to roughly the same period. Moreover, they were produced in the areas to which Clm 6298 can be also assigned. Just like the Munich manuscript, the three oldest witnesses contain only a small selection of glosses. Of these three, only one contains material that appears in $\mathrm{Clm}$ 6298, namely Würzburg 47. This manuscript was copied in an unknown German Anglo-Saxon centre in the late eighth or early ninth century and has the works of Gregory the Great as its principal content. ${ }^{12}$ The three last folia of this codex are filled with a selection of the EvII glosses on all Gospels, among them also EvII $58,{ }^{13}$ which features at the end of the section on Matthew in this manuscript: ${ }^{14}$ 'Commonis ubiubi aelimosine congregentur'. Apart from the excerpts from EvII, the manuscript contains excerpts from the first batch of Canterbury glosses on the Gospels (EvI) in the first folio.

The two other manuscripts that contain sections of EvII do not include EvII 58-9. ${ }^{15}$ Würzburg 38 was copied at Würzburg in the second third of the

9 The Rz glosses are edited in E. von Steinmeyer and E. Sievers, Die althochdeutschen Glossen. Ergänzungen und Untersuchungen, 5 vols. (Berlin, 1922) V, 135-225. The Leiden Glossary is discussed in Lapidge, 'The School of Theodore and Hadrian', pp. 54-8.

${ }_{10}$ Bischoff and Lapidge, Biblical Commentaries, pp. 286-7. Bischoff, 'Turning-points', pp. 75-6.

11 See Bischoff and Lapidge, Biblical Commentaries, pp. 289-90.

12 Description in H. Thurn, Die Handschriften der Universitätsbibliothek. Würzburg 3.1: Die Pergamenthandschriften der ehemaligen Dombibliothek. (Wiesbaden, 1984), pp. 36-7. Bischoff and Lapidge consider it an early-ninth-century manuscript, following CLA; Bischoff and Lapidge, Biblical Commentaries, p. 290. Lapidge also considers an origin in Kent on account of the presence of the glosses; M. Lapidge, The Anglo-Saxon Library (Oxford, 2005), n. 73.

13 The gloss can be seen in $\mathrm{f} 72 \mathrm{v}$. Digital facsimile of the manuscript at: http://vb.uni-wuerzburg. $\mathrm{de} / \mathrm{ub} /$ permalink/mpthf47.

14 The last gloss on Matthew present in the Würzburg manuscript is EvII 62, which is the last gloss in the section on Matthew also in the Milanese manuscript. In the former, it is preceded by EvII 58, while in the latter, there are three other glosses in between the two, as is clear from the numbering in the edition.

15 The overview of the three manuscripts, other than the principal manuscript, containing EvII glosses can be found in Bischoff and Lapidge, Biblical Commentaries, pp. 289-90. 


\section{Evina Steinova}

ninth century. ${ }^{16}$ Apart from works of the Church Fathers it contains thirteen glosses on the Gospel of Matthew corresponding approximately to EvII 3-29. ${ }^{17}$ Munich Clm 14470 is a homiliary copied around 800 in South Bavaria and preserved later at St Emmeram in Regensburg. ${ }^{18}$ Just like Clm 6298, it contains scribal additions, among which are three glosses on Luke, EvII 115, 117 and $119 .{ }^{19}$

These diverse selections from EvII provide important evidence that the commentary was known and available in some form, whether in its entirety or an abridged version, in two regions at the end of the eighth and during the ninth century. The two Würzburg manuscripts attest that the material was available, in its entirety or in part, in the German Anglo-Saxon missionary area. The selection from the EvII in Würzburg 47, moreover, shows that the text of the commentary was already known here around the turn of the ninth century and that, in the form that it had at the time, it included at least one of the glosses found in Clm 6298. In the same manner, Clm 14470 provides evidence that the EvII glosses were also available in some form in the early ninth-century Bavaria. However, it may be noted that, unlike those of the two Würzburg manuscripts, both of which contain glosses on Matthew, the glosses in Clm 14470 are on Luke only. It might thus perhaps be that only a selection from EvII was available at the location where this manuscript was copied, such as a gloss-commentary on Luke only. This is something that should be considered when the possible origin of the fragment of EvII in Clm 6298 is considered.

$$
\text { MUNICH, CLM } 6298
$$

Clm 6298 fits well into the wider picture that emerges from the examination of the three early witnesses of EvII. The manuscript, also known as the Homiliary of St. Korbinian, contains the homilies of Caesarius of Arles and other homiletic material copied in a clear Anglo-Saxon minuscule dated to the late eighth century. ${ }^{20}$ Its place of origin has not been identified yet. Schlecht called it a Freising product in 1924, ${ }^{21}$ but Bischoff challenged this attribution and in his Südostdeutschen Schreibschulen und Bibliotheken in der Karolingerzeit. He reassessed the manuscript as a product of a continental Anglo-Saxon centre. He personally

16 Description in Thurn, Die Handschriften der Universitätsbibliothek. Würzburg, p. 28.

17 In $123 \mathrm{v}-124 \mathrm{r}$; the manuscript is digitized at: http://vb.uni-wuerzburg.de/ub/mpthf38/ ueber.html.

18 Description in K. Bierbrauer, Die vorkarolingischen und karolingischen Handschriften der Bayerischen Staatsbibliothek (Munich, 1990), n. 151.

19 In 121r; at: http://daten.digitale-sammlungen.de/bsb00022361/image_256.

20 Description in Bierbrauer, Die vorkarolingischen und karolingischen Handschriften, n. 219.

21 J. Schlecht, Wissenschaftliche Festgabe zum zwölfhundertjährigen Jubiläum des Heiligen Korbinian (Munich, 1924), p. 208. 


\section{Munich, Bayerische Staatsbibliothek, CLM 6298}

favoured the region of Mainz and Fulda, ${ }^{22}$ for which reason Spilling associated it directly with Fulda. ${ }^{23}$ Based on the decoration of the manuscript, however, Weiner has suggested most recently that the place of origin might have been Würzburg, a view that was tentatively accepted by Glauche and Bierbrauer in the new catalogues of the Bayerische Staatsbibliothek. ${ }^{24}$ Lapidge follows Lowe's dating and localization in the Codices Latini Antiquiores and retains the Mainz-Fulda-Würzburg region in his Anglo-Saxon Library. ${ }^{25}$

The manuscript found its way to the cathedral library of Freising by the twelfth century as is indicated by the twelfth-century ownership mark in $1 \mathrm{r}$ : Liber iste est sancte Marie et sancti Corbiniani Frisinge. However, the book might have travelled to Freising as early as in the ninth century. Bischoff, following Schlecht, suggested that the subscription of one Amalric (Amalricus) in $3 \mathrm{r}$ - the same folio where the two glosses can be found - could belong to the subdeacon and priest of the same name attested in Freising in $827 .{ }^{26} \mathrm{He}$ dates Amalric's hand and 'the other hand' of $3 r$ to the ninth century and points out that Amalric's hand displays insular influence. ${ }^{27}$ In Scbreibscbulen Bischoff strongly expresses the opinion that none of the hands in the manuscript is of Freising origin, presumably including the hands of Amalric and of the others who made entries in 3r. Bischoff also hypothesizes that Amalric came to Freising from the Northwest and that perhaps he was the one who brought

22 B. Bischoff, Die südostdentschen Schreibschulen und Bibliotheken in der Karolingerzeit: die vorwiegend österreichischen Diözesen, 2 vols. (Wiesbaden, 1940) I,141-2.

${ }^{23}$ H. Spilling, 'Das Fuldaer Skriptorium zur Zeit des Hrabanus Maurus', Hrabanus Maurus: Lehrer, Abt und Bischof, ed. R. Kottje and H. Zimmermann (Wiesbaden, 1982), pp. 165-81, at 180.

${ }^{24}$ See Bierbrauer, Die vorkarolingischen und karolingischen Handschriften, p. 110; and Glauche, Katalog der lateinischen Handschriften, p. 171.

25 CLA IX, 1264. Lapidge, The Anglo-Saxon Library, n. 55. Lowe also noted that the notices by Amalric in 3r 'have a Fulda-Mainz appearance' and that the probation omnium inimicorum, which can be seen in $3 \mathrm{r}$ and $14 \mathrm{v}$, is to be found in several Würzburg manuscripts.

${ }_{26}$ Bischoff, Die südostdeutschen Schreibschulen und Bibliotheken in der Karolingerzeit, p. 142. The only other subscription in the manuscript can be found in $16 \mathrm{v}$ and $18 \mathrm{v}$, lower margins, and belongs to one Hartwin (Hartunin). What may be a name of another scribe, Ammnan, is to be found in 17r, upper margin. An Amalric (Amalrib) is listed in the Freising section of the Liber confraternitatis of Reichenau; Libri confraternitatum Sancti Galli Augiensis Fabariensis, ed. P. Piper, MGH Necrologia Germaniae Supp. (Berlin, 1884), 322 (II 549, 2). The name is part of a younger addition to the Freising list which, according to the editor, was made under the bishop Erchanbert (835-54); ibid. p. 321. Perhaps then this Amalrib is identical with the Amalricus of Clm 6298. No Hartwin is mentioned in the Freising list.

${ }^{27}$ B. Bischoff, Katalog der festländischen Handschriften des neunten Jabrbunderts (mit Ausnabme der wisigotischen), II: Laon-Paderborn (Wiesbaden, 2004), n. 3036a. Bischoff, Die südostdeutschen Schreibschulen und Bibliotheken in der Karolingerzeit, p. 142. Bischoff mentions only Amalric as the maker of notes displaying Insular influence in the Katalog, ignoring the other hands on 3r. Glauche does not say anything about the number or provenance of the hands on 3r, although he sticks with the ninth century as the date of their origin; Glauche, Katalog der lateinischen Handschriften, p. 171. 


\section{Evina Steinova}

the codex to Freising. ${ }^{28}$ Nevertheless, Bavaria, and Freising specifically, should be considered a potential locus where the glosses were added to $\mathrm{Clm}$ 6298, as it is impossible to know precisely when and where the note-making happened.

Both areas with which Clm 6298 can be connected, Bavaria and the MainzFulda-Würzburg region, are the places where EvII is attested in the period when Clm 6298 was copied and annotated. If the codex reached Bavaria in the early ninth century, Clm 6298 can be taken as an example of the trend discussed by Bischoff and Lapidge: the migration of the Canterbury material from the region of the Anglo-Saxon mission southwards into the area of St. Gall and Bavaria around the turn of the ninth century. ${ }^{29}$

Three observations seem to point to a German rather than Bavarian provenance of the glosses in Clm 6298. First, none of the hands active in $\mathrm{Clm}$ 6298 was identified by Bischoff as Bavarian. Quite the contrary, he argued for the Anglo-Saxon character of all hands, presumably including those in 3r. Moreover, four of the five witnesses of the PentI-EvII cluster ${ }^{30}$ are from the German Anglo-Saxon area and only one, the youngest, from Bavaria. Finally, while we have evidence that the glosses on Matthew circulated in the former region, we lack direct evidence that the Matthew material was available in Bavaria. The only witness from that area contains only glosses on Luke, and while this does not exclude the possibility that the Matthew material was also available in the region, the two Würzburg manuscripts seem to be more closely related to Clm 6298 by virtue of their interest in Matthew.

THE OTHER MATERIAL IN 3 R AND ITS BEARING ON THE BIBLICAL GLOSSES IN CLM 6298

The position of the glosses in $3 \mathrm{r}$ of $\mathrm{Clm} 6298$ indicates that the note-maker who added them worked only after the two pieces to which Amalric's subscription belongs were entered; it thus provides us with a relative date. The only piece of text in $3 \mathrm{r}$ that can be considered more recent than the insert containing the two glosses, since it is scribbled in the last patch of parchment left empty below the three notices, is a verse from the possibly 'Hiberno-Latin' composition Audax es vir invenis: ${ }^{31}$

28 Bischoff, Die südostdeutschen Schreibschulen und Bibliotheken in der Karolingerzeit, p. 142.

29 Bischoff and Lapidge, Biblical Commentaries, p. 291.

30 As was noted above, the two commentaries are linked together by means of similar structure. The PentI glosses feature in two manuscripts from the Anglo-Saxon missionary area in Germany. These are St. Gallen, Stiftsbibliothek 913 (s. viii ${ }^{2}$ ) and Berlin, Staatsbibliothek der Stiftung Preussischer Kulturbesitz, Grimm 132, 2 frg. (s. viii ${ }^{\text {med }}$ ). The glosses in the St. Gallen manuscript can be seen at: http://www.e-codices.unifr.ch/en/csg/0913/139/medium.

31 D. Schaller, E. Könsgen and T. Klein, Initia carminum Latinorum saeculo undecimo antiquiorum: bibliographisches Repertorium für die lateinische Dichtung der Antike und des früheren Mittelalters. 


\section{Munich, Bayerische Staatsbibliothek, CLM 6298}

Carnem tuam consenties/ animam tuam decipis/ dum flecteris ad libidinem/ male deceptus remanens (permanens a.c.)/ ad[...]

At least from the ninth century, this verse was transmitted as part of a selfcontained alphabetical composition, called Versus de contemptu mundi in one of its witnesses, ${ }^{32}$ and featuring also among the Carmina Cantabrigensia. ${ }^{33}$

The two glosses in Clm 6298 do not stand alone. They are part of a larger notice made by a single hand that consists of three separate entries. I transcribe them here for reference and discuss them below:

(1) 'Quattuor turbas sequebantur dominum. Una propter sanitatem corporis. Alia propter fabulas. Tertia propter reprehensionem. Quarta propter vitam aeternam.' (top of the page, above the second notice by Amalric)

(2) Ev II 58-59 (below the second notice and the subscription of Amalric)

(3) 'Duo in lecto illi significantur qui remoti a turbis in otio quidam vitae iacere videntur, duo molientes qui negotiis temporalium rerum circumferuntur, duo in agro qui in ministerio ecclesiae, tamquam in agro dominico operantur, ex quibus adveniente nocte quidam permanent in fide, et adsumentur ad vitam quidam decedunt et relinquentur ad poenam.' (directly below the glosses)

The three notices in $\mathrm{Clm} 6298$ share certain features that indicate that they may have belonged to a single source text or corpus of material, and are likely to have been copied with the same design. They all refer to and were excerpted from biblical commentaries on the Gospels. Notice (3) is an excerpt from Isidore's Allegoriae quaedam sacrae scripturae $194-6,{ }^{34}$ suitable, given the sequence of the biblical imagery, as a commentary on Luke XVII.34-5. Yet, it could have also been linked to Matthew XXIV.40-1, where the same apocalyptic prophecy is treated, albeit the two in lecto are not mentioned by Matthew. I point out this possible connection to Matthew because (1) and (2) certainly refer to Matthew: (2), as was shown, belongs to Matthew XXVII.6 and 56, and (1), as will be discussed below, to Matthew V.1. All three items, thus, might

Supplementband (Göttingen, 2005), n. 1305. This verse was not transcribed or identified by Glauche.

32 Cf. Poetae latini aevi Carolini, ed. K. Strecker, MGH Poetae Latini 4 (Berlin, 1923), 496 and Die Cambridger Lieder, ed. K. Strecker, MGH Scriptores rerum Germanicarum 40 (Berlin, 1926), 52. The textual variants in $C \operatorname{lm} 6298$ show affiliation with the text of the versus in manuscripts Cologne, Dombibliothek, 106 (Werden, s. ix ${ }^{\text {in }}$ ) and Brussels, Koninklijke Bibliotheek 88608867 (St. Gallen, s. x). The alphabetic rhythmic composition was printed by Migne under Bede's work as Bede, Hymni de die iudicii, PL 94, col. 558c.

33 This compilation, however, dates to the eleventh century, although it contains older material; Die Cambridger Lieder, ed. Strecker, pp. ix-x.

${ }^{34}$ Isidore of Seville, Allegoriae quaedam sacrae scripturae, PL 83, col. 123c. It is the only piece made by this hand that was also identified by Glauche. An overview of early manuscripts of the Allegoriae in C. H. Beeson, Isidor-Studien, Quellen und Untersuchungen zur lateinischen Philologie des Mittelalters 4.2 (Munich, 1913), 27-32. 
have come from a commentary or other type of exegetical text on the Gospel of Matthew.

Moreover, notice (1), enumerating the different crowds following Christ, seems to have a 'Hiberno-Latin' tinge. ${ }^{35}$ Bischoff considered enumeration a trait characteristic of what he called the 'Hiberno-Latin' tradition of exegesis. ${ }^{36}$ Wright has also shown that many of the enumerative passages found in the early medieval compendia can be traced to Irish exegetical and ecclesiastical traditions and were also known in Anglo-Saxon England. ${ }^{37}$ Another reason to consider notice (1) of a piece with the 'Hiberno-Latin' exegetical tradition is the fact that the theme of crowds is absent from Patristic commentaries and commentaries produced by the Carolingian exegetes, ${ }^{38}$ but can be found in precisely those exegetical texts labeled as 'Hiberno-Latin'. ${ }^{39}$ The

35 Given the problematic nature of this term, I will use it in this fashion.

36 Bischoff, 'Turning-points', p. 84. Gorman, on the contrary, argued that enumeration is typical in exegesis of the seventh and the eighth century in general and should not be seen as an Irish symptom; M. Gorman, 'A Critique of Bischoff's Theory of Irish Exegesis: the Commentary on Genesis in Munich Clm 6302 (“Wendepunkte” 2)', JML 7 (1997), 178-233, at 205. Gorman was in turn criticized by Wright, who pointed out that while enumeration as such is not particularly Irish, enumeration was particularly popular in Irish and Irish-influenced exegesis, in which it was extended to a number of themes not found elsewhere; C. D. Wright, 'Bischoff's Theory of Exegesis and the Genesis Commentary in Munich clm 6302: a Critique of a Critique', JML 10 (2000), 115-75, at 149.

37 C. D. Wright, 'The "enumerative style" in Ireland and Anglo-Saxon England', in his The Irish Tradition in Old English Literature (Cambridge, 1993), at pp. 49-105. Unfortunately, although Wright discusses many exegetical themes written in enumerative fashion, he does not mention the crowds following Christ.

${ }^{38}$ I examined the Tractatus in Matthaeum of Chromatius of Aquileia; Hraban Maur's Expositio in Matthaeum; Otfried of Weissenburg's Glossae in Matthaeum, Defensor's Liber Scintillarum; Bede's Expositio in Matthaei evangelium; Jerome's Commentarii in evangelium Matthaei; as well as other works of Jerome and Augustine. Unfortunately, I was unable to check the commentary on Matthew by Claudius of Turin.

39 I was able to examine only some of the commentaries listed in Bischoff, 'Turning-points'; and in M. Gorman, 'The Myth of Hiberno-Latin Exegesis', RB 110 (2000), 42-85. Where possible, I tried to consult the commentaries in their original manuscript form. I also consulted some of the exegetical florilegia listed in Wright, "The "enumerative style". In the anonymous commentary on Matthew preserved in Munich, Bayerische Staatsbibliothek,

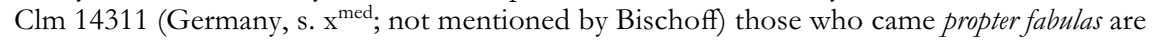
not mentioned among the four listed crowds, but instead there is a crowd that seeks alms (ut elymosinam acciperet); 32v, at: http://daten.digitale-sammlungen.de/bsb00046624/image_67. In the commentary to Matthew in Munich, Bayerische Staatsbibliothek, Clm 6302 (Freising, s. viii ${ }^{2}$; Bischoff's no. 24) four crowds mentioned include those who came propter gulam and alii propter miracula, but not those who sought physical well-being and parables; 40v, at: http://daten.digitale-sammlungen.de/bsb00047253/image_84. In the Irish reference Bible, Munich, Bayerische Staatsbibliothek, Clm 14427 (s. ix in ; Bischoff's no. 1A), four crowds mentioned include one that came pro admiratione turbarum, but none that came propter fabulas; 235v, at: http://daten.digitale-sammlungen.de/bsb00046657/image_70. In the commentary on Matthew from Munich, Bayerische Staatsbibliothek, 6233 (?Tegernsee, s. viiiex; Bischoff's 


\section{Munich, Bayerische Staatsbibliothek, CLM 6298}

theme of crowds seems to have been connected both to Matthew IV.25 ('et secutae sunt eum turbae multae de Galilaea et Decapoli et Hierosolymis et Indaea et de trans Iordanen') and to Matthew V.1 ('Videns autem turbas ascendit in montem et cum sedisset accesserunt ad eum discipuli eius'). The exact number and characterization of the crowds, however, differed in each commentary. Only three of the commentaries I surveyed refer to four crowds as (1) does, and characterize them in terms akin to those found in Clm 6298 - the recensio I of the Expositio quatuor evangeliorum, a 'Hiberno-Latin' Gospel commentary from the late seventh century attributed to Jerome, ${ }^{40}$ on Matthew V.1.41 the Liber quaestionum in evangeliis, a 'Hiberno-Latin' composition from the first quarter of

no. 23), only three crowds are mentioned in the commentary to Matthew IV.25; $75 \mathrm{r}$, at: http://daten.digitale-sammlungen.de/bsb00054475/image_153. Commentary on Matthew V.1 in this manuscript does not reflect the theme. Sedulius Scottus refers to six crowds in his exposition of Matthew IV.25, but does not discuss the crowds in connection with Matthew V.1; see In evangelium Matthaei I.i.4. The Liber de numeris also mentions six crowds only; cf. Munich, Bayerische Staatsbibliotheek, Clm 14392 (Freising, s. ix ${ }^{\text {in }}$; not mentioned by Bischoff), fols. 98v-99r, at: http://daten.digitale-sammlungen.de/bsb00046512/ image_198. The Cracow homily collection, Krakow, Biblioteca Capitulare 140 (Italy, s. viii ${ }^{\text {ex }}-\mathrm{ix}^{\text {in }}$; not mentioned by Bischoff), contains a rather long elaboration on the crowds following Christ, but speaks of six crowds only; cf. P. David, 'Un recueil de conférences monastiques irlandaises du VIII siècle: notes sur le manuscrit 43 de la bibliothèque du chapitre de Cracovie', RB 49 (1937), 62-89, at 76-7. The Catechesis Celtica, Vatican, Biblioteca Apostolica Vaticana, Reg. Lat. 49 (Britanny/Wales, s. ix ${ }^{\text {ex }}-\mathrm{x}^{\text {in }}$; not mentioned by Bischoff), displays verbatim parallels with the Liber quaestionum in evangeliis in the section devoted to the Sermon on the Mount, but neither in the case of Matthew IV.25 nor Matthew V.1, according to Rittmueller; J. Rittmueller, 'MS Vat. Reg. 49 Reviewed: A New Description and a Table of Textual Parallels with the Liber questionum in euangeliis', Sacris Erudiri 33:1 (1992), 259-305, at 271. The commentary on Matthew preserved in Vienna, Österreichische Nationalbibliothek, Cod. 940 (Salzburg, s. viii ${ }^{\text {ex }}-\mathrm{ix}^{\text {in }}$; Bischoff's no. 17 I), five crowds are mentioned in the passage referring to Matthew V.1, in 40v. The theme does not feature in the Florilegium Frisingense, Munich, Bayerische Staatsbibliothek, Clm 6433 (Freising, s. viiie ${ }^{-}$ ix $\left.^{\text {in }}\right)$; in Prebiarium de multorium exemplaribus, Munich, Bayerische Staatsbibliothek, Clm 6302 (Freising, s. viii ${ }^{2}$ ); in the Collectanea psendo-Bedae; in the exegetical collection in Munich, Bayerische Staatsbibliothek, Clm 19410 (Tegernsee, s. ix ${ }^{\mathrm{med}}$ ); or in the exegetical collection in Munich, Bayerische Staatsbibliothek, Clm 22053 (region of Augsburg, s. ix ${ }^{\text {in }}$ ). Absence of the theme from florilegia, as opposed to the Gospel commentaries, seems to imply that it is indeed to be connected with a commentary proper rather than an exegetical compilation of another type.

40 See M. Lapidge and R. Sharpe, A Bibliography of Celtic-Latin Literature, 400-1200 (Dublin, 1985), pp. 97-8; and Bischoff, 'Turning-points', n. 11A, pp. 108-9. Some of the twenty-seven manuscripts given by Bischoff are listed in F. Stegmüller, Repertorium biblicum medii aevi, 11 vols. (Madrid, 1951) III: nos. 3424-7.

41 VIDENS AUTEM IESUS TURBAS [Matthew V.1]. Item quatuor turbae secutae sunt Christum, et ipsae quatuor sequuntur Ecclesiam: prima ut Christum per timorem et amorem, item ad Ecclesiam ueniunt: secundo, qui pro cupiditate cibi aut potus: tertia, pro inuidia, ut habeant quod accusent: quarta doctores; Expositio evangeliorum, PL 30, cols. 543d-4b. The Expositio also refers to six crowds in connection with Matthew IV.25. 


\section{Evina Steinova}

the eighth century, ${ }^{42}$ also on Matthew V.1 $;{ }^{43}$ and the Würzburg commentary on Matthew from the early ninth century, ${ }^{44}$ once again on Matthew V.1. ${ }^{45}$

Given the agreement in number and characteristics of the crowds, but discrepancies in their sequence, as well as the phrasing of the passage, (1) seems to reflect a variant of the exegetical theme that is echoed in the three commentaries, but itself was not directly taken from any of them. Perhaps it can be considered a re-working of the theme that could have been based on these commentaries. Given that a number of early medieval exegetical texts remain unedited and inaccessible, however, it cannot be ruled out that there once existed a direct source text or manuscript for this fragment of exegetical lore, one that would correspond more closely to (1) than the three commentaries mentioned above, but which escaped me, or which is now lost. In any case, both the Liber quaestionum in evangeliis and the Expositio quatuor evangeliorum were widely available on the Continent, ${ }^{46}$ particularly in contrast to other 'HibernoLatin' exegetical texts, many of which survive only in a single manuscript.

42 J. Rittmueller, Liber quaestionum in Evangeliis, CCS 108F (Turnhout, 2003), 11. Dated to the first half of the eighth century by Lapidge and Sharpe; Lapidge and Sharpe, A Bibliography of Celtic-Latin Literature, par. 764. MacNally dates it to the second half of the eighth century; R. E. MacNally, The Bible in the Early Middle Ages, Woodstock papers 4 (Westminster, Maryland, 1959), 106. See also Bischoff, 'Turning-points', n. 16 I.

43 TURBAS [Matthew V.1]. Turba non unius uoluntatis est. Hae uero Christum sequebantur: perfecti, ut apostoli; inperfecti, ut Pharisaei; infirmi, ut leprosi; cibo et nestitu indigentes; curiosi tantum nerba audire uolentes; Rittmueller, Liber quaestionum in Evangeliis, p. 88.

${ }^{44}$ Unlike the two other commentaries, the Würzburg commentary on Matthew is a unique dossier of material preserved in a single manuscript, Würzburg, Universitätsbibliothek, M.p.th.f. 61. The main text of the Gospel in this manuscript was produced in Ireland in the second half of the eighth century; the commentary in the form of annotations in a Continental Irish centre at the beginning of the ninth century. The manuscript is described in Thurn, Die Handschriften der Universitätsbibliothek. Würzburg, pp. 44-5. See also Lapidge and Sharpe, $A$ Bibliography of Celtic-Latin Literature, n. 768; Bischoff, 'Turning-points', n. 22; and M. Cahill, 'The Würzburg Matthew: status quaestionis', Peritia 16:1 (2002), 1-25. Despite being preserved today in Würzburg 61, it has no detectable affiliation with the region, but was rather produced partially in Ireland and partially in a continental Irish colony. Moreover, it is textually related to the Liber quaestionum in evangeliis as is obvious from the fact that the passage on Matthew V.1 is virtually identical in the two commentaries

45 VIDENS AUTEM IESUS [Matthew V.1]. Turba non unius uoluntatis, bae nero turbae Christum sequebantur: perfecti ut apostoli, inperfect $<\mathrm{i}>$ ut Pharisaei, infirmi ut leprosi, cibo et uestitu indigentes, curiosi, qui<ppe> uerba tantum audire nolentes. C. Köberlin, 'Eine würzburger Evangelienhandschrift (Mp. th. f. 61, s. VIII.)', Programm zu dem Jahresberichte der kgl. Studienanstalt bei St. Anna in Augsburg (Augsburg, 1891), 3-95, at 45.

46 The Liber quaestionum in evangeliis was employed by Hraban Maur, Haimo of Auxerre and Paschasius Radbertus, as well as by Sedulius Scottus, and was likewise known in the AngloSaxon continental centres; Rittmueller, Liber quaestionum in Evangeliis, pp. 43-7, where the reception of the work as well as surviving manuscripts are discussed. As for the Expositio quatuor evangeliorum, Bischoff mentions twenty-seven manuscripts of the first recensio of the commentary and around forty manuscripts of all versions; Bischoff, 'Turning-points', n. 11A. 


\section{Munich, Bayerische Staatsbibliothek, CLM 6298}

Unfortunately, the theme of the four crowds, as it appears in (1), does not help to assess $\mathrm{Clm}$ 6298, nor to contextualize the insertion of the excerpt from Ev II into the manuscript.

\section{CONCLUSION}

The two Canterbury glosses in Clm 6298 corroborate the picture we already have of the fate of this commentary corpus on the Continent. The manuscript displays affiliation with both Anglo-Saxon mission centres in Germany and with Bavaria, and if we accept an early date for its sojourn, it exemplifies the migration of the Canterbury matter from one region to another at the time when the glosses were added to the codex. The fact that the glosses in $\mathrm{Clm}$ 6298 may be considered fragments of a whole is also significant, as this is also the case with other manuscripts containing the same material in the period. Again, Clm 6298 seems to exemplify a trend that is known from the period. The glosses in Clm 6298, furthermore, appear in the vicinity of other exegetical material that may be associated with the Gospel of Matthew or else with the Gospels in general, suggesting that perhaps the excerption was guided by a particular design or corresponded to a particular arrangement in a lost source text.

No decisive conclusions about the place where the two glosses were entered into the pages of $\mathrm{Clm} 6298$ can be reached at this point, nor is it possible to say when and by whom they were added. The different arguments presented in this article seem to tilt the scales, nevertheless, slightly towards the AngloSaxon centres in Germany rather than Bavaria as the place where the notices were made, although they are by no means watertight and may turn out to be purely coincidental in the end. If we accept Wiener's suggestion that Clm 6298 might have originated at Würzburg, and thus that this was the place where the glosses might have been added too, it is particularly tempting to see a connection between the homiliary and Würzburg 38, since the latter indicates that at least portions of the EvII commentary were available in Würzburg in the later decades of the ninth century. ${ }^{47}$ Unfortunately, such a hypothesis remains speculative, and only further research may reveal more about how this piece fits into the puzzle called the Canterbury biblical commentaries.

${ }^{47}$ Note also the book list from Würzburg where a volume bearing the name glosa is listed. As Lapidge remarks, it could contain material such as the Canterbury biblical commentary; Lapidge, The Anglo-Saxon Library, pp. 148-51. 